\title{
ВАСПИТНИ СТИЛ РОДИТЕЉА И РЕЛИГИОЗНОСТ СТУДЕНАТА
}

\author{
Марина Матејевић ${ }^{1}$, Светлана Стојановић \\ Универзитет у Нишу, Филозофски факултет, \\ Департман за педагогију
}

\begin{abstract}
Ancmpaкm: У оквиру овог рада, бавимо се васпитним стилом родитеља и религиозношћу студената. Васпитне стилове, према теоријском концепту Д. Бомрајнд, ауторитативни, ауторитарни и пермисивни, сагледавамо кроз њихове димензије, први преко димензија повезаност, регулација и аутономија, а други преко димензија принуда, вербална хостилност, необјашњавање. Религиозност, према схватању Глука и Старка, сагледавамо преко димензија веровање, ритуалност и последице. Истраживање је организовано са циљем утврђивања повезаности васпитног стила родитеља и религиозности студената. Коришћена је дескриптивна метода, техника скалирања, као инструменти, скале процене. Испитано је 200 студената са различитих универзитета у Србији, који су процењивали васпитне поступке својих родитеља, оца и мајке одвојено, и њихов однос према религиозности. Резултати истраживања показују да је најзаступљенији васпитни стил ауторитативни, да су васпитни стилови родитеља повезани са полом студената, социоекономским статусом породице и местом становања. Просечна оцена религиозности студената повезана је са полом студената и местом становања, а према димензији ритуал и са образовањем оца. Једина повезаност васпитног стила родитеља и религиозности студената, негативна је, и односи се на принуду као димензију ауторитарности оца и ритуал и последице, као димензије религиозности, што значи да израженија принуда од стране оца подразумева мање изражену религиозност у области практичне религиозности. Показало се да је религиозност, заиста, специфичан феномен који је прилично тешко реално сагледати и квантитативно исказати, а наша препорука је да то треба чинити, комбиновањем квантитативног и квалитативног приступа, уважавањем плурализма научних парадигми како би се избегло једнозначно тумачење прикупљених чињеница, што би омогућило интегрално, мултидисциплинарно разумевање проблема.
\end{abstract}

Кључне речи: родитељи, васпитни стил, религиозност, студенти

\footnotetext{
${ }^{1}$ email: marina.matejevic@filfak.ni.ac.rs

* Ово истраживање финансијски је подржало Министарство просвете, науке и технолошког развоја Републике Србије.
} 


\section{1. Васпитни стил родитеља}

Истраживања васпитног стила родитеља почела су 30 -их година XX века у САД-у. Аутори су васпитни стил родитеља врло различито одређивали. Неки аутори сматрају да се најделотворнијим и најпродуктивнијим показао модел E. C. Шефера (Schaefer, E. S. 1959: 231), који је пошао од 32 аспекта бриге мајке према детету и факторским поступком их редуковао на две међусобно независне димензије васпитања: афективну димензију и димензију контроле. Афективна димензија представља емоционални однос родитеља према детету и омеђена је половима „топло“ и „хладно“ или одбијајуће и прихватајуће васпитање. Друга васпитна димензија, димензија контроле приказује дозвољену психичку и физичку слободу и самосталност детета. Омеђена је половима „попустљиво“ и „ограничавајуће“ васпитање или аутономност и контрола.

У разумевању васпитног стила родитеља, пошли смо од теоријског концепта Д. Бомрајнд (Baumrind, 1991: 65-67), која је ослањајући се на Шеферов модел, дефинисала три основна типа односа родитељ-дете: ауторитарни, ауторитативни и пермисивни. Ауторитарни васпитни стил, према Бомрајдовој се односи на поступања родитеља који имају висока очекивања и захтеве за своју децу, првенствено зато што су нетолерантни, строги, очекују послушност и показују моћ када се њихова деца недолично понашају. Ауторитарни родитељи исказују своје захтеве и очекивања и не комуницирају са децом о разлозима који стоје иза тих правила. Они очекују апсолутну послушност своје деце и често прибегавају јаким казненим мерама чим се дете удаљи од стндарда који су поставили. Сваки дијалог се обесхрабрује са образложењем да је родитељска реч последња.

Ауторитативни васпитни стил према Бомрајндовој карактерише родитеље који охрабрују вербалну комуникацију и иницијативу детета, они са дететом заједно доносе закључке. Ауторитативни родитељи препознају своја посебна права као старије особе, али и посебна интересовања детета, они препознају тренутне квалитете детета, али постављају и стандарде за понашање убудуће. Ауторитативни родитељи испољавају опште прихватање праћено израженом вербалном комуникацијом, што најчешће има исходе у успешном прилагођавању, независности и социјалној одговорности. Компетентност ауторитативних родитеља Бомрајдова је повезала са инструменталном компетентношћу њихове деце. Инсртументална компетентност (Baumrind, Thompson, 2002: 14-15) односи се на понашање које је друштвено одговорно и независно, понашање које је пријатељски, а не непријатељски настројено према вршњацима, даље се односи на кооперативност, а не одбојност према одраслима, достигнућа а не неуспехе, доминантност а не субмисивност, циљано, а не бесциљно понашање. За разлику од ауторитативних, пермисивни, попустљиви родитељи, сматра Баумринд, покушавају да се понашају тако да не кажњавају, већ прихватају и одобравају импулсе, жеље и поступке детета. Они деци постављају мање захтева за одговорност у домаћинству и уредно понашање, али се у сушти- 
ни детету представљају као помоћно средство које ће дете користити кад пожели, а не као активно средство одговорно за обликовање и промену његовог тренутног или будућег понашања. Ови родитељи дозвољавају детету да уређује своје активности, колико год је то могуће избегавају вежбе контроле, и не охрабрују дете да поштује стандарде дефинисане од спољашњег света. Попустљиви родитељи су више респонзивни него што су захтевни. Пермисиван стил обележава ниска контрола праћена ниским захтевима уз опште прихватање детета, што за последицу најчешће има ниску социјалну одговорност и привидну независност детета. Овај васпитни стил карактерише висок ниво бриге и јасноће у комуникацији, али низак ниво контроле и захтева за зрелошћу. Попустљиви родитељи дозвољавају детету слободу у бирању активности, прихватају и подржавају понашање детета и чине мало напора да спроведу контролу над њим или да поставе стандарде понашања.

Под васпитним стилом се подразумевају релативно доследни начини понашања родитеља, којима се успостављају укупни односи са децом (Matejević, 2007: 58-59). Као такви, васпитни стилови се фомирају веома рано и дете их усваја као модел родитељског понашања. Породица треба да представља средину у којој ће дете моћи несметано да се развија. То је могуће тек када су све његове природне потребе задовољене и тиме створени адекватни услови за социјално, емоционално и интелектуално функционисање, чему различити васпитни стилови родитеља дају специфичне доприносе.

\section{2. Религија и религиозност}

Религија прожима све сегменте људског живота, између осталог, и васпитање и образовање. Сваки облик васпитања полази од схватања да се на свест и осећања младог човека може утицати на унапред одређен начин, као стварање и развијање одређених сазнајних, моралних, културних и емоционалних особина личности. На тај начин схваћено, васпитање и образовање остварује индиректан утицај и на формирање религиозности, јер се религиозност испољава управо у оквиру поменутих сегмената личности (Avramović i Kuljić, 2009).

Током историјског развоја, образовање је у већој или мањој мери било повезано са религијом, али је са процесима модернизације и глобализације дошло до потискивања религије, уместо религије, настају нови облици друштвене свести, под чијим је утицајем судбина човека све неизвеснија (Ivanović, 2015).

Дефиниције религиозности и религије су бројне, а заједничко свим дефиницијама и свим религијама, огледа се у томе што се у основи религиозног уверења човека налази веровање у постојање натприродног, духовног, трансценденталног или светог бића које утиче на људски живот, као и на сва збивања у природи и друштву (Mladenović i Knebl, 1999). У том смислу, религија као људска, културно-историјска чињеница, располаже специфичним системом идеја, веровања и праксе, представљајући својеврсни облик практичног одношења према свету, природи, друштву и човеку, како наводи Ђорђевић (1999). Он при- 
мећује да се религија различито схвата, одређује, вреднује, некада је у политичкој милости, некада не, прати мене епохалних дешавања, па у одређеној, за њу повољној епохи, или исечку епохе, задобија примат, постаје доминантна и боји време, да би у другим околностима изгубила првенство, забацила изворност и сишла испод освојеног цивилизацијског нивоа. Аврамовић и Куљић (2009) истичу да религија има неколико друштвено-културних функција: сазнајну, културну, комуникативну, етичку, психолошку, идентитетску, интегративну, легитимацијску, политичку. Уз то објашњавају да је друштвени живот један изузетно сложен процес који појединац и групе не могу да смисаоно обухвате на целовит начин, те због тога стварају свој поглед на свет који им омогућава да разнолика искуства тумаче на специфичан начин. Религија је, сходно наведеном, један од погледа на свет, односно једно схватање смисла живота, у оквиру ког се материјалном свету супротставља духовни, чиме би требало да се религија уздигне изнад појединачних достигнућа цивилизације и развије интегрални приступ животу, без подела на науке и дисциплине. Позитивно конфесионално изјашњавање постало је облик националног идентификовања, изражавања традиционалне породичне припадности једној конкретној религији, и стога не мора представљати актуелну и активну везаност за религију и цркву (Đorđević i Todorović, 1999), нити подразумева директне импликације на понашање и живот човека, што све скупа, додатно отежава покушаје истраживања религиозности, и узрока и последица који се за њу могу везати.

Религиозност можемо схватити као испољавање личне привржености одређеној религији. Она поред спољашње манифестације учешћа у обредима религијске природе представља и индивидуални став, субјективни доживљај, унутрашњи мотив који је теже операционализовати у социолошким истраживањима религије и религиозности, па је комплементарност истраживачких техника (на пример психолошких) нешто што се само по себи намеће и доприноси поштовању основног методолошког начела у емпиријским истраживањима да се у стварању социолошке искуствене научне евиденције користи више истраживачких техника, па и из других научних дисциплина (Blagojević, 2009). Hajчешће коришћени термини у литератури којима се покушава представити човеков однос према религији јесу теизам (прихватање постојања Бога и веровање у њега), агностицизам (недоследан и нејасан однос према Богу и религији, особа ни сама не зна да ли верује или не) и атеизам (неприхватање постојања Бога) (Dušanić, 2011). Међутим, у овом раду користимо термин религиозност који сматрамо обухватнијим од термина теизам, јер се употребом другог узима у обзир само сфера веровања, док се први односи и на сферу религијског понашања, што сматрамо важним за наше истраживање.

Религиозност, у свом општем смислу, представља свеобухватан социолошки термин којим се означавају бројни аспекти верске активности, посвећености и веровања (верске доктрине), па и верских очекивања која имају јак утицај на све аспекте личног живота (Azam et al., 2011), у чему се и огледа њен практични значај. У покушају што једноставнијег одређивања религиозности, Лебедев истиче да критериујум (православне) религиозности треба одредити 
са три битна обележја као неопходна и довољна услова религиозности: религиозна вера као животни смисао за верника (прво), која се конкретизује кроз позитивну религијску (друго) и конфесионалну самоидентификацију (треће обележје) (Lebedev, 2005). Међутим, у истраживањима, религиозност се обично поистовећује са припадањем одређеној конфесији, о којој се испитаници или изјашњавају самостално или заокружују једну од понуђених опција, док се као друга могућност појављује коришћење скале религиозности на основу које се идентификују, односно процењују, уверења о постојању више силе, интензитет обављања религијских радњи, интензитет личне комуникације са Богом, религијска посвећеност испитаника једних у односу на друге (Todorović i Knežević, 2006). Ми смо се у овом раду одлучили за другу опцију, сматрајући да она, у односу на прву, омогућава нешто дубље продирање у религиозни живот испитаника.

\section{3. Димензије религиозности}

Целовитији увид у религијски феномен и религиозност људи се пре може постићи вишедимензионалним него једнодимензионалним или дводимензионалним приступом, јер се тиме спречава реална могућност да се у истраживању занемаре неке димензије религије и религиозности за које се после покаже да су важне, а без којих се значајно сужава феномен који испитујемо, апстраховањем неких страна религије и религиозности као небитних, или њиховим свесним потискивањем (Blagojević, 2012). Осим тога, Благојевић наводи да су најзаслужнији аутори за афирмацију вишедимензионалног приступа, шездесетих година прошлог века, Глок и Старк (Glock \& Stark, 1965 prema: Wening \& Choerudin, 2015). Иако је њихов мултидимензионални приступ много пута у емпиријским истраживањима тестиран и прошириван, и данас је актуелна подела на пет димензија религиозности коју су они дали. Без обзира на сложеност, све светске религије имају неке заједничке сфере у којима се религиозност манифестује (религиозно искуство, ритуалистичка димензија (религиозна пракса), идеолошка димензија (религиозна веровања), интелектуална димензија (религиозно знање) и последична димензија религиозности).

Димензија религиозног искуства се односи на очекивање да ће религиозна особа постићи директно знање о последњој реалности или да ће искусити религиозна осећања у форми егзалтације, страха, понизности, радости и спокоја. Поред тога ова димензија подразумева осећајно и перцептивно искуство у ситуацијама успостављања комуникације са Богом, различита мистична искуства, као и искуства иницијације.

Идеолошка димензија или димензија религиозних веровања заснива се на скупу ставова појединаца спрам неког вишег бића или моћи, схваћених као трансцендентних или тајанствених, из чега следи очекивање да ће религиозна особа прихватити одређена веровања, а као емпиријски показатељи користе се догматска веровања углавном јудео-хришћанске религијске традиције. Рели- 
гијско веровање подразумева укупност структуралних потреба људског бића, укупност стратегија за задовољење тих потреба, процесе социјализације које спроводе установе (цркве, школе, породица) са циљем преношења садржаја неког религијског веровања и њиховог претварања у друштвену праксу и етичке ставове.

Ритуалистичка димензија религиозности подразумева специфичну религиозну праксу и обреде које испуњавају припадници религије било индивидуално било колективно речима, гестовима, симболима, преко којих верници ступају у везу са Богом на богослужењу, у молитвама, празновањем религијских празника, где је посебно важно са каквим мотивима верници прилазе одржавању религијских обреда.

Интелектуална димензија или димензија религијске спознаје, односи се на очекивања да ће религиозна особа бити упозната са основним начелима своје вере, са догматским истинама вере као и са светим списима вере. Познавање вере се односи на пример на историју властите религије, на познавање важних чињеница везаних за веру, за интелектуално читање светих списа и друге религијске литературе. Свакако, ова знања су важна не само за религију јер се она преко њих легитимише, него и за сваког верника који је ближе повезан са својом вером.

Последична димензија религиозности представља значење вере за живот - религиозност у човековом субјективитету, утицај религиозних уверења на свакодневни живот човека, и подразумева све оно што би верници требало да чине, па чак и ставове које би требало да имају управо као последицу тога што су верници одређене религијске традиције. Ова димензија се може одредити и као директна последица религијске вере на различите сфере друштвеног понашања верника, најпре у породици, али и у економији, политици, животу у смислу односа човека према другом човеку, једном речи ради се о димензији која подразумева религијске импликације на практичан живот верника.

Утицај религиозности на карактеристике и понашање појединца различито се тумачи и доводи у везу са различитим корелатима, некад се инсистира на позитивном, некад, пак, на негативном утицају религије. Утицај религиозности неминовно постоји, а интерпретација његовог карактера зависи од контекста истраживања. Услови породичног живота и породично васпитање умногоме диктирају формирање не само ставова о религији, већ генерално имају пресудну улогу и утицај на формирање личности (Bakrač, 2011), те због тога и доводимо у везу васпитни стил родитеља и религиозност студената.

\section{4. Методолошки приступ}

Истраживање је оганизовано са циљем да се утврди да ли постоји повезаност васпитних стилова родитеља и религиозности студената, као и њихова повезаност са социодемографским варијаблама. Пошли смо од претпоставке да постоји повезаност између васпитног стила родитеља и религиозности сту- 
дената. У истаживању је примењена дескриптивна истраживачка метода и скалирање као инстраживачка техника, у оквиру које су коришћене скале за утврђивање васпитног стила родитеља и религиозности студената.

За утврђивање васпитног стила родитеља коришћена је скала процене васпитног стила родитеља PSDQ, Parenting Styles and Dimensions Questionnaire (Robinson, Mandleco, Olson and Hart, 2001), садржи димензије ауторитативног, ауторитарног и пермисивног стила, према моделу Бомрајндове. Димензије ауторитативног стила су повезаност (Oтаи)/мајка ме охрабрује да слободно исказујем своје мишљење), регулација (Наглашавао/ла је који су разлози одређених правила) и аутономија (Дозвољавао/ла ми је да утичем на правила y породищи), и чине први фактор упитника. Димензије ауторитарног стила су принуда (Кажнавао/ла ме је када сам био/ла непослушан/на), вербална хостилност (Викао/ла је на мене када сам се лоше понашао/ла) и необјашњавање (Кажнавао/ла ме је тако што ме је остављао/ла самог/му са мало или без имало објашњењь), које чине други фактор. Трећи фактор односи се на пермисивни стил који нема посебне димензије (Отац/мајка ме је размазио/ла).

За утврђивање религиозности студената коришћена је скала процене религиозности коју је на основу теоријског концепта Глока и Старка конструисао и редуковао Дамир Љуботина (prema: Stiplošek, 2002). Скала религиозности првобитно израђена према пет димензија религиозности (веровање, ритуал, искуство, знање, последице) садржала је 32 тврдње. Након примене, Љуботина ју је редуковао, и сада се састоји од 24 честице које се могу разврстати у три димензије, у сваку димензију по 8 ставки. Те димензије су: димензија духовности која означава веровање, затим ритуална и димензија утицаја вере на понашање. У овом случају религиозност представља лични избор и може се разматрати као примарни аспект вере. Пример тврдње из скале која одговара првој димензији је: Понекад осећам присутност Бога или неког Божанског бића. Ритуална димензија религиозности подразумева упражњавање различитих обреда прописаних од стране верске заједнице (нпр. Редовно одлазим y цркву). Димензија утицаја вере на понашање представља примену верских начела у свакодневном животу (нпр. Нисам присталица брака с припадницима друге религије). Распон резултата на скали је од 0 до 72. Већи резултат указује на већу религиозност.

Поузданост на основу интерне конзистенције употребљених инструмената у истраживању

Анализирајући резултате о поузданости инструмената коришћених за потребе овог истраживања, приликом приписивања релијабилности скалама процене, придржавали смо се препорученог критеријума, према коме се за скалу са коефицијентом релијабилности већим од 0.7 може рећи да релијабилна (DeVellis, 2003; Nunnally, 1978). Скала процене васпитног стила оца коју смо користили за потребе истраживања, садржи 32 ајтема, а применом Кромбах алфа теста (Cronbach's Alpha) утврдили смо да је коефицијент поузданости 0.830, што сведочи о поузданости података прикупљених у оквиру истраживања васпитног стила оца. За скалу процене васпитног стила мајке израчунати 
коефицијент поузданости који износи 0.786 што сведочи о поузданости и ове скале. Скала процене религиозности коју смо користили за потребе истраживања, садржи 24 ајтема, а применом Кромбах алфа теста (Cronbach's Alpha) утврдили смо да је коефицијент поузданости 0.962, што сведочи о поузданости података прикупљених у оквиру истраживања религиозности студената, према препорученом критеријуму ( $>0.7)$.

За потребе истраживања испитани су студенти Филозофског факултета Универзитета у Новом Саду, Филолошког факултета и Православног богословског факултета Универзитета у Београду, и студенти Универзитета у Нишу, Филозофског, Медицинског, Правног и Природно-математичког факултета. Реч је о пригодном узорку. Испитано је 200 студената укупно, односно 33 студента мушког и 167 женског пола.

Табела 1. Структура узорка према полу

\begin{tabular}{lcccc}
\hline Пол & Фреквенција & $\%$ & Валидни \% & Кумулативни \% \\
\hline Мушки & 33 & 16,5 & 16,5 & 16,5 \\
\hline Женски & 167 & 83,5 & 83,5 & 100,0 \\
\hline Укупно & 200 & 100,0 & 100,0 & \\
\hline
\end{tabular}

Што се тиче структуре узорка према образовању родитеља, узорак чини шесторо студената чији очеви имају само основну школу и 71 студент чији су очеви високо образовани. Очеви више од половине студената $(61,5 \%)$ завршили су средњу школу.

Табела 2. Структура узорка према образовању оца испитаника

\begin{tabular}{ccccc}
\hline Образовање оца & Фреквенција & $\%$ & Валидни \% & Кумулативни \% \\
\hline Основно & 6 & 3,0 & 3,0 & 3,0 \\
Средње & 123 & 61,5 & 61,5 & 64,5 \\
Високо & 71 & 35,5 & 35,5 & 100,0 \\
Укупно & 200 & 100,0 & 100,0 & \\
\hline
\end{tabular}

Узорком је обухваћено осморо студената чије мајке имају само основну и 177 студената чије су мајке завршиле и средњу школу. Удео високообразованих мајки $(37,5 \%)$. 
Табела 3. Структура узорка према образовању мајке испитаника

\begin{tabular}{ccccc}
\hline Образовање мајке & Фреквенција & $\%$ & Валидни \% & Кумулативни \% \\
\hline Основно & 8 & 4,0 & 4,0 & 4,0 \\
\hline Средње & 117 & 58,5 & 58,5 & 62,5 \\
\hline Високо & 75 & 37,5 & 37,5 & 100,0 \\
\hline Укупно & 200 & 100,0 & 100,0 & \\
\hline
\end{tabular}

Мали број студената процењује статус своје породице као низак $(6,5 \%)$, односно висок (6\%). Највећи део студената обухваћених узорком $(87,5 \%)$ процењује социоекономски статус своје породице као осредњи.

Табела 4. Структура узорка према социоекономском статусу породице

\begin{tabular}{lllll}
\hline Статус породице & Фреквенција & $\%$ & Валидни \% & Кумулативни \% \\
\hline Низак & 13 & 6,5 & 6,5 & 6,5 \\
\hline Осредњи & 175 & 87,5 & 87,5 & 94,0 \\
\hline Висок & 12 & 6,0 & 6,0 & 100,0 \\
\hline Укупно & 200 & 100,0 & 100,0 & \\
\hline
\end{tabular}

Да студенти претежно живе у граду потврђује податак из табеле 5, где видимо да $80 \%$ студената живи у градској средини, а свега $20 \%$ у сеоској.

Табела 5. Структура узорка према месту живљења испитаника

\begin{tabular}{ccccc}
\hline \multirow{2}{*}{ Место живљења } & Фреквенција & $\%$ & Валидни \% & Кумулативни \% \\
\hline Село & 40 & 20,0 & 20,0 & 20,0 \\
\hline Град & 160 & 80,0 & 80,0 & 100,0 \\
\hline Укупно & 200 & 100,0 & 100,0 & \\
\hline
\end{tabular}

Истраживање је спроведено прослеђивањем инструмента на друштвеној мрежи. Иструмент је за потребе истраживања преведен у форму коју подржава Google disk сервис, и у тој форми је прослеђиван студентима који су исти постављали на студентским групама на друштвеној мрежи. Тиме смо постигли да испитивање буде потпуно анонимно и засновано на принципу добровољности.

За статистичку обраду података коришћен је програм SPSS Statistics 20.0 (for Windows) помоћу ког смо утврдили величину узорка (N), аритметичку средину (M), стандардну девијацију (sd), фреквенције и проценте (\%), релијабилност скале процене (Cronbach's Alpha Test), Пирсонов коефицијент корелације (r), ниво статистичке значајности (p). 


\section{5. Резултати истраживања и дискусија резултата}

Поређењем аритметичких средина, увидели смо да родитељи студената највише примењују ауторитативни васпитни стил, затим пермисивни, а најмање ауторитарни. Добијени резултати су у складу са налазима истраживања Матејевић и Тодоровић ( Матејевић, Тодоровић, 2012 : 101), где је такође најзаступљенији ауторитативни васпитни стил родитеља студената Универзитета у Нишу, што је и у скалду са истраживањима повезаности академског постигнућа адолесцената и васпитног стила родитеља. Значајно је такође да је необјашњавање као поступак најмање изражено код оба родитеља, што сматрамо позитивним, јер оно представља вид одбацивања личности васпитаника и може јако лоше да утиче на развој. И код очева и код мајки је најизраженија димензија повезаност, ауторитативног васпитног стила, с тим што је средња оцена повезаности код мајки нешто виша. Заправо, гледано према свим димензијама, оцене васпитних поступака мајки су више, вероватно због веће укључености мајке у процес васпитања, добијени налази приказани су у табели 6.

Табела 6. Заступљеност васпитних стилова родитеља према димензијама

\begin{tabular}{llcc}
\hline & Отац & $\mathrm{M}$ & $\mathrm{SD}$ \\
\hline \multirow{2}{*}{ Ауторитативност } & Повезаност & 3,3 & 1,38912 \\
\cline { 2 - 4 } & Регулација & 3,16 & 1,33541 \\
\cline { 2 - 4 } & Аутономија & 3,055 & 1,27676 \\
\hline Ауторитарност & Принуда & 2,315 & 1,28218 \\
\hline \multirow{2}{*}{ Пермисивност } & Вербална хостилност & 3,235 & 1,25204 \\
\hline \multirow{2}{*}{ Ауторитативност } & Необјашњавање & 1,495 & 0,90224 \\
\hline \multirow{2}{*}{ Ауторитарност } & Мајка & 2,6 & 1,4213 \\
\hline & Повезаност & $\mathrm{M}$ & $\mathrm{SD}$ \\
\hline & Аугулација & 3,78 & 1,27662 \\
\hline & Прономија & 3,43 & 1,2093 \\
\cline { 2 - 4 } & Необбална хостилност & 3,495 & 1,26808 \\
\hline
\end{tabular}

Пермисивност

$2,815 \quad 1,43214$

Према резултатима дескриптивне статистике просечни скор студената на скали религиозности је $M=31,64$, а то је нешто мања вредност од средњег скора 
на скали, узимајући у обзир да је максимални могући скор 72, и не може се рећи да сведочи о високој религиозности студентске популације. Највиши скор студенти су остварили према димензији веровање, што је и очекивано, с обзиром на то да ова димензија укључује опште ставове о односу према Богу и вери. Димензија ритуал је у средини по изражености, означавајући основне показатеље привржености религији, као што је поштовање празника или обављање обреда. Најмањи скор везује се за димензију последице, која подразумева практични утицај религије на функционисање појединца и доношење ставова и одлука, и уједно означава најдубљи уплив религије у живот човека. Резултати су приказани у табели 7.

Табела 7. Дескриптивна статистика - религиозност

\begin{tabular}{lll}
\hline & \multicolumn{1}{c}{ M } & \multicolumn{1}{c}{ SD } \\
\hline Религиозност & 31,6400 & 20,23456 \\
\hline Веровање & 11,7500 & 8,01929 \\
\hline Ритуалност & 11,2700 & 7,38443 \\
\hline Последице & 8,6200 & 6,63897 \\
\hline
\end{tabular}

Испитивање повезаности религиозности студената и димензија васпитних стилова родитеља показало је да је религиозност негативно повезана са принудом као димензијом ауторитарног стила оца, и то је једини случај икакве повезаности васпитног стила и религиозности, односно њихових димензија.

Табела 8. Повезаност религиозности и васпитног стила оца

\begin{tabular}{cccc}
\hline & & Религиозност \\
\cline { 2 - 4 } Ауторитарност оца & Принуда & $\mathrm{R}$ &,- 167 \\
& & $\mathrm{P}$ &, 018 \\
\hline
\end{tabular}

Детаљнија анализа поменуте повезаности, показала је да је принуда од стране оца повезана са димензијама ритуалност и последице. Реч је о обрнутој повезаности, на основу које закључујемо да израженија принуда корелира са мање израженом ритуалношћу и последицама, као димензијама религиозности.

Табела 9. Повезаност димензија религиозности и ауторитарности оца

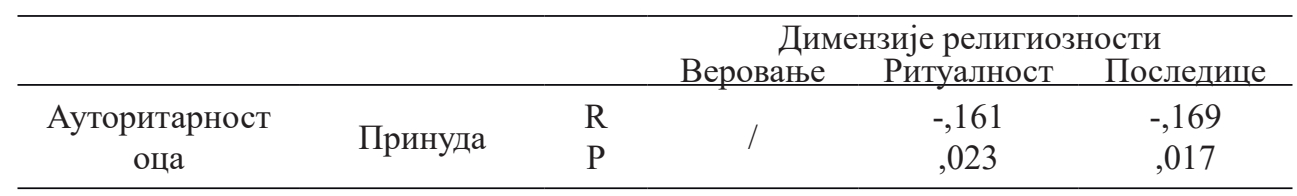


Принуда као димензија васпитног стила, односи се на кажњавање у случају непослушности и недисциплине, обично без обзира на оправдање детета. Са друге стране, ритуалност и последице, као димензије религиозности, подразумевају укљученост у религијски живот, промене сопственог функционисања ради усклађивања са идеалима вере, обављање обреда и слично. Могло би се рећи да принуда у васпитању доводи до несигурности, или неповерења, што се, у случају религиозности, манифестује кроз задржавање на површном односу према вери, кроз опште ставове и рефлексије, са што мањим утицајем религије на животно функционисање. Заправо, принуда се може тумачити и као извор бунта младих, који се огледа у избегавању односа које карактерише хијерархија улога, избегавајући тиме и могућност да поново буду кажњавани. У том случају, демонстрација моћи и злоупотреба породичне хијерархије од стране оца, рефлектује се на појам младих о хијерархији уопште, те они процењују проблематичном и хијерархију која се може приписати религијским односима, и бирају да се не уплићу претерано у односе који за њих представљају могући извор лошег искуства.

Истраживање је такође показало да су пол студената, ниво образовања оца и место становања негативно повезани за религиозношћу, што значи да је религиозност мање изражена код испитаница, односно код студената чији су очеви високо образовани и који су из града. Према таквим налазима студенти мушког пола, односно студенти чији су очеви мање образовани и који су са села, уједно су приврженији религији. Утврђено је да је религиозност према димензијама ритуалност и последице више изражена код испитаника мушког пола. Разлог разлика религиозности према полу проналазимо у чињеници да су истраживањем обухваћени студенти Православног богословског факултета, који су, без сумње, религиознији од осталих испитаника, што је и довело до статистички значајне повезаности са димензијама ритуалност и последице, jep је за њих потпуно очекивано да су позив одабрали због спремности да се посвете Богу, кроз све оно што подразумевају димензије религиозности које се односе на практичну примену веровања кроз живот.

\section{Закључак}

Иако на нашем поднебљу опстаје уверење да су очеви ауторитарни, а мајке пермисивне, показало се да је код оба родитеља заступљен првенствено ауторитативни стил, с тим што су мајке добиле нешто вишу оцену. Заправо, гледано према свим димензијама, оцене васпитних поступака мајки су више, вероватно због веће укључености мајке у процес васпитања.

Религиозност је повезана са местом становања студената, као и са нивоом образовања оца, што значи да су студенти у граду и студенти - деца образованијих очева мање религиозни, док су студенти са села и они чији су очеви мање образовани, више религиозни. То нас упућује на закључак да не само васпитни стил родитеља, већ и религиозност студената зависи од средине у којој млади живе и развијају се. 
Резултати нашег истраживања показали су да не постоји статистички значајна повезаност васпитних стилова родитеља и религиозности студента, те закључујемо да општа хипотеза истраживања, о повезаности васпитних стилова родитеља и религиозности студената није потврђена, истичући, притом, да повезаност постоји само у случају принуде оца као васпитног поступка и ритуалности и последица као димензија религиозности, која је, узгред, негативна. Оваква повезаност указује на мање изражену религиозност студената чији родитељи користе принуду као васпитни поступак, односно да су студенти чији очеви имају наклоност ка поступцима који се могу окарактерисати као ауторитарни, мање привржени религији.

Показало се да је религиозност, заиста, специфичан феномен који је прилично тешко реално сагледати и квантитативно исказати. Она представља својеврстан начин живота који се артикулише под утицајем најразличитијих фактора, посебно оних којима се наука не бави, и због тога ју је готово немогуће теоријски формулисати. Религиозност је димензија живота која није погодна за научну операционализацију и анализирање по стандардима применљивим за друге параметре живота. Она је нешто друго. Танани, интимни доживљај, који се не може исказати редовним одласцима у цркву или познавањем богослужења (нити било којом другом ставком из бројних инструмената за мерење религиозности). Са друге стране, она је врло индивидуална ствар, и одређени ниво религиозности свакако је најподеснији унутрашњим и спрољашњим чиниоцима функционисања индивидуе, али не и статистичким параметрима процене. Ипак, појединачне науке не одустају од покушаја спознавања феномена религиозности са свим његовим специфичностима, а наша препорука је да то треба чинити удружено, комбиновањем квантитативног и квалитативног приступа, уважавањем плурализма научних парадигми како би се избегло једнозначно тумачење прикупљених чињеница, а омогућило интегрално, мултидисциплинарно разумевање проблема везаних за религију и религиозност.

\section{Литература}

Avramović, Z. i Kuljić, R (2009). Sociološki pristupi religiji. Sociološki godišnjak, (4), 45-76.

Azam, A., Qiang, F., Abdullah, M. I. \& S. A. Abbas (2011). Impact of 5-D of Religiosity on Diffusion Rate of Innovation. International Journal of Business and Social Science, 2(17), 177-185.

Baumrind, D. (1991). The influence of parenting style on adolescent competence and substance use. Journal of Early Adolescence, Berkeley, vol. 11, 56-95.

Baumrind, D., Thompson, A. R. (2002). The Ethics of Parenting, In M. Bornstein (Ed.), Handbook of Parenting, Vol. 5. Practical Issues in Parenting, LEA, Mahwah, New Jersey London.

Bakrač, V. (2011). Religioznost mladih u Crnoj Gori i njihov odnos prema nekim moralnim vrijednostima. Sociološka luča, 5(2), 16-28. 
Blagojević, M. (2009). O sociološkim kriterijumima religioznosti - Koliko ima (pravoslavnih) vernika danas? Filozofija i društvo, 20(1), 9-36.

Blagojević, M. (2012). Religijsko-konfesionalna identifikacija i vera u Boga građana Srbije. Filozofija i društvo, 23(1), 40-52.

DeVellis, R. F. (2003). Scale Development: Theory and Applications. Thousand Oaks, California: Sage.

Dušanić, S. (2011). Karakteristike religiozne sumnjičavosti kod mladih. Psihološka istraživanja, 14(1), 47-66.

Đorđević, D. B. (1999). Religija i nauka: religijsko obrazovanje u školi. U: Mladi, religija, veronauka. Niš: KSS, 73-80.

Đorđević, D. B. i Todorović, D. (1999). Stavovi mladih u Jugoslaviji o nacionalnoj, konfesionalnoj i religijskoj pripadnosti. U: Mladi, religija, veronauka. Niš: KSS, 31-50.

Ivanović, S. (2015). Obrazovanje između religije i sekularizacije. Inovacije u nastavi, 28(2), 13-17.

Лебедев, С. (2005). Религиозность в поисках „рубикона“. Социиологический журнал, 153-169

Matejević, M. (2007). Vrednosne orijentacije i vaspitni stil roditelja. Niš: Filozofski fakultet.

Matejević, M. D. i J. A. Todorović (2012). Funkcionalnost porodičnih odnosa $i$ kompetentno roditeljstvo. Niš: Filozofski fakultet.

Mladenović, U. V. i J. Knebl (1999). Religioznost, aspekti self-koncepta i anksioznost adolescenata. Psihologija, 32(1-2), 83-96.

Nunnally, J. C. (1978). Psychometric theory. New York : McGraw-Hill.

Robinson, C. C., Mandleco, B., Olsen, S. F., \& Hart, C. H. (2001). The Parenting Styles and Dimensions Questionnaire (PSQD). In: B. F. Perlmutter, J. Touliatos, \& G. W. Holden (Eds.), Handbook of family measurement techniques: Vol. 3. Instruments \& index (pp. 319-321).

Schaefer, E. S. (1959). A Circumplex model for maternal behavior. Journal of Abnormal and Social Psyhology, vol. 59, 226-235.

Stiplošek, D. (2002). Povezanost religioznosti, samopoštovanja i lokusa kontrole (neobjavljen diplomski rad). Zagreb: Filozofski fakultet.

Todorović, A. i G. Knežević (2006). Povezanost prisustva sekularno opisanih spiritualnih doživljaja sa dve različite mere religioznosti. Psihologija, 39(4), 509-526.

Wening, N. \& A. Choerudin (2015). The Influence of Religiosity Towards Organizational Commitment, Job Satistfaction and Personal Performance. Polish Journal of Menagement Studies, 11(2), 181-191. 


\title{
PARENTING STYLE AND STUDENTS' RELIGIOSITY
}

\author{
Marina Matejević, Svetlana Stojanović \\ University of Niš, Faculty of Philosophy, \\ Department of Pedagogy
}

\begin{abstract}
In this paper, we deal with parenting style and students' religiosity. Parenting styles, according D. Baumrind, authoritative, authoritarian and permissive, are viewed through their dimensions, the first through dimensions of connections, regulation and autonomy, and the second through dimensions of coercion, verbal hostility and notexplaining. Religiosity, according Glock and Stark, is viewed through the dimensions of belief, ritual and consequences. The survey was organized with the aim of finding a correlation between parenting style and religiosity of students. We used descriptive methods, scaling techniques, as instruments, assessment scales. The sample consisted 200 students from various University of Serbia, who evaluated the parental procedures of their parents, father and mother separately, and expressed personal views about religiosity. Results of the research show that the most common parental style is authoritative, that the parental styles of parents associated with sex of students, socio-economic status of the family and place of residence. The average score of students' religiosity is associated with sex and place of residence of students, and according to the ritual dimension with fathers education. The only connection between parenting style and religiosity of students, is negative, and refers to coercion as a dimension of fathers authoritarianism and ritual and consequences, as well as the dimensions of religiosity. So, there is no statistically significant correlation between parenting style and religiosity of students, in general terms, except the coercion as a fathers parental procedure which is associated with ritual religiosity and consequences, in terms that the coercion pronounced by the father means less expressed practical religiosity. It turned out that religiosity is, indeed, a specific phenomenon that is quite difficult to realistically perceive and quantify, and our recommendation is to do so by combining quantitative and qualitative approaches, respecting the pluralism of scientific paradigms to avoid unambiguous interpretation of collected facts, which would enabled an integral, multidisciplinary understanding of the problem.
\end{abstract}

Keywords: parents, parenting style, religiosity, student

Цитирање чланака: Матејевић, М. и Стојановић, С. (2020). Васпитни стил родитеља и религиозност студената. Годишњак за педагогију, 5(1), 7-21. 